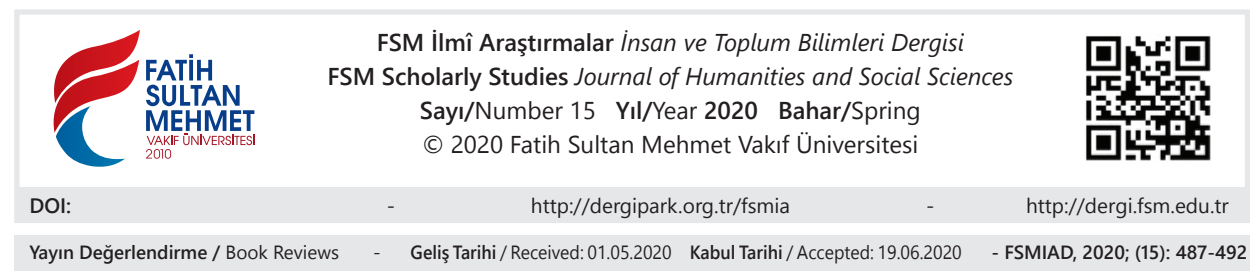

\title{
Rıza Yıldırım, Aleviliğin Doğuşu Kızılbaş Sufiliğinin Toplumsal ve Siyasal Temelleri 1300-1501,
}

İstanbul: İletişim, 2018, 9789750522383, $400 \mathrm{~s}$.

Murat Berkan Kuşkonmaz

İlk defa 2017 yılında Barış Yıldırım tarafından Türkçe’ye çevirilen Aleviliğin Doğuşu', İletişim Yayınları'nın baskısıyla aynı yılda ilk kez okuyucuların karş1sına çıktı ve kısa bir süre içerisinde 2018 yılında ikinci baskısını yaptı. Çalışma, yazar Rıza Yıldırım'ın 2008 yılında Bilkent Üniversitesi Tarih Bölümü’nde tamamlamış olduğu doktora tezine ${ }^{2}$ dayanmakta olup aslında tezin ilk kısmının Türkçe'ye tercümesidir.

1998 yılında Bilkent Üniversitesi Fizik Bölümü’nden mezun olan Rıza Y11dırım, aynı üniversitenin Tarih Bölümü’nde yüksek lisans eğitimini 2001 yılında tamamladı. İlerleyen dönemde akademik kariyerine aynı bölümde devam eden Yıldırım, Halil İnalcık danışmanlığında 2008 yılında tamamladığı “Turkomans Between Two Empires: The Origin Of The Qizilbash Identity In Anatolia (14471514)" başlıklı tezi ile Doktor ünvanını aldı. Günümüzde çalışmalarını yurt d1şında yürüten Yıldırım, Emory Üniversitesi’nde ikinci doktora eğitimine devam etmektedir.

Lisans Öğrencisi, Fatih Sultan Mehmet Vakıf Üniversitesi Edebiyat Fakültesi Tarih Bölümü, İstanbul/Türkiye, m.kuskonmaz@stu.fsm.edu.tr, orcid.org/0000-0002-0835-0510

1 Rıza Yıldırım, Aleviliğin Doğuşu Kızılbaş Sufiliğinin Toplumsal ve Siyasal Temelleri 13001501, İstanbul, 2018.

2 Riza Yıldırım, "Turkomans Between Two Empires: The Origins Of The Qizilbash Identity in Anatolia (1447-1514)", (Yayımlanmamış Doktora Tezi), Bilkent Üniversitesi Sosyal Bilimler Enstitüsü, Ankara, 2008. 
400 sayfadan müteşekkil olan kitap, giriş ve sonuç bölümleri hariç beş ana bölümden oluşmaktadır. Her bölüm kendi içerisinde konularına göre çeşitli alt başlıklara ayrılmıştır. "Alevilik nedir?" sorusu ile başlayan eserde bu sorunun cevabına dair tanımlamalar getirmeye çalışan yazar, tanımlama konusunun problematiğine ve tanımların göreceliğine ilişkin kısa bir değerlendirme yapar. Aynı zamanda yazar hayatından kesitleri okuyucuya sunarak zikredilen sorunun tez yazım aşamasında üretilmediğini, daha ziyade ilkokul çağından itibaren içinde bulunduğu sosyal ortamın bir tezahürü olarak daima aklının bir köşesinde bulunduğunu belirtir. Böylece yazar çalışmasının kendisi için sahip olduğu farklı yönünü vurgular.

Yıldırım, esas olarak Aleviliğin ne'liğine dair bir şablon sunmaktan ziyade Kızılbaş-Aleviliğinin doğuşunu incelemektedir. Bu minvalde yazar, alanda yapılan pek çok çalışmanın aksine konuyu sadece dinî ya da siyasi yönden ele almamış çalışmaya ayrıca antropolojik ve sosyo-ekonomik boyutlar da kazandırmayı hedeflemiştir.

Yazar'a göre çalışmanın ana konusunu oluşturan Kızılbaş telakkisi, tarihsel boyutta bakıldığında Türklerin erken devirlerine kadar götürülebilmekle beraber bugünkü manada kimliksel bir zeminin üzerine oturması 15. yüzyılda gerçekleşmiştir. Zikredilen dönemde Safeviler'in ortaya çıkışı ve Osmanlı Devleti ile siyasal ve düşünsel alanda başlayan mücadelesi, Kızılbaşlık kavramının, zıddı olan Osmanlı emperyal düşüncesi ile var olup kemikleşmesini sağladı.

Yukarıda zikredilen Kızılbaş telakkisinin oluşumu ve inkişafını sağlayan ana unsur, Yıldırım'ın da altını çizdiği göçebe Türkmen kabileleriydi. Bu özelliklerinden dolayı eser aslında Türkmenler'in bir çeşit serüveni niteliğini taşır. Yakındoğu'nun iki büyük gücü olan Osmanlılar ve Safeviler için bahsi geçen göçebe gruplar aslında bir çeşit zamanın ruhuydu. Bu ruha uyan iki devlet kuruluş dönemlerinde göçebe yapıları yanlarına çekerek kısa sürede teşekküllerini tamamlamış ve yükselmeyi başarmışlardı. Fakat burada dikkat edilmesi gereken husus Safeviler'e görece çok daha erken bir devirde Osmanlılar'ın kuruluşunda yer alan Türkmenler'in, kısa bir süre sonra Safeviler'in oluşumunda aktif rol oynayarak Osmanlılar karşısında kendilerini konumlandırdıkları yeni kimliğin temellerinin nereye dayandığıdır. İşte bu sorunun cevabını arayan yazar öncelikle göçebe kabile yapılarına antropolojik ve sosyolojik bir mercekten bakmaya çalışır ve okuyucuya gelecek bölümlerdeki okumalar için teorik bir alt yapı sunar. $\mathrm{Bu}$ minvalde kabile örgütlenmesi, kabile ve devlet arasındaki farklılaşma ve bu iki yapının çatışma unsurları sosyo-politik yönden incelenmiş, Khazanov, Lindner ve Barfield gibi alanın uzmanlarından yapılan karşıllaştırmalı alıntılar ile ileri sürülen düşünceler genel bir zemine oturtulmuştur. 
Yazar, daha sonraki süreçte aşiret yapılarına dair sunduğu teorik çerçeveyi Osmanl1-Türkmen ilişkileri üzerinden somutlaştırmaya çalışır ve Osmanlı Devleti'nin kuruluşu ve gelişimini izleyen süreçte dönüşümü sağlayan ana unsur olarak Türkmenler'in rolüne değinir. Zikredilen bu gruplar başlangıçta oldukça kritik bir öneme sahipken zaman içinde Osmanlı merkezileşmesi ile doğru orantılı olarak merkezden uzaklaşmışlardır. Yıldırım'a göre bu dönüşümü meydana getiren bazı unsurlar vardır. Bunlar ilmiye sınıfı, kalemiye sınıfı ve düzenli ordudur. Özetle bürokratikleşme süreci aynı zamanda Yıldırım'a göre eski düzenin kurucuları olan göçebelerin idari, askeri ve dinî alanlardan çekilmesi ile birlikte meydana gelen bir süreçti. Bu doğrultuda idari alandan çekilen Türkmen reislerin yerini İranî-İslam geleneğine göre tahsil yapmış olan bürokratlar, ordudan çekilen gazilerin yerini merkeze sadakat ile bağlı ve çoğunluğu yabanc1 unsurlardan müteşekkil kapıkulları, dinî alandan çekilen heterodoks sufi çevrenin yerini ise yerleşik Sünni akımı temsil eden medreseli ulema almıştı. Devletin üç saç ayağında meydana gelen bu tasfiye süreci bir yandan aşiret gruplarını merkez dışına iterken öteki yandan Osmanlı Beyliği'nin devletleşmesini sağlıyordu. Yukarıda zikrettiğimiz üç alanda meydana gelen dönüşümü ayrıntılı bir şekilde ele alan yazar konuya dair geniş bir perspektif sunar. Buradan çıkarılan sonuç ise önce merkez dışına itilen daha sonra burada da yalnız bırakılmayarak gelişmiş devlet mekanizmaları ile kayıt altına alınmak istenen, aşiret sistemlerine müdahale edilen Türkmenlerin yeni bir arayış içine girdikleridir. Özetle merkezileşme denilen olgu kabileleşmeyi azaltıyordu ve bu durum aşiret grupları arasında bir nefret uyandırmıştı.

Sistemden uzaklaşan Türkmenler Ankara Savaşı'nda Timur'un, beylikler ile olan mücadelede Karamanlılar'ın ve Otlukbeli'nde Uzun Hasan'ın yanında yer almışlardı. 15. yüzyılın ortalarından itibaren ivme kazanan Osmanlı karşıtı arayış bu grupların son olarak Safeviler yanında yer almasına neden olmuştu. Yazar ise bu doğrultuda zikredilen arayıştan hareketle Safeviyye tarikatının devletleşmeye giden sürecini ayrıntılı bir şekilde ele almaya başlar. Devletin temeli olan tarikatın kurucusu Şeyh Safi'nin rüyası ile başlatılan süreç ilk etapta Şah İsmail'in babası Haydar'a kadar getirilir böylece Şah İsmail'i meydana getiren arka plan incelenir.

Safeviyye tarikatının dönüşüm sürecinden hareketle Yıldırım'ın literatüre getirdiği en önemli yenilik ve kitabın önemini arttıran unsur bizce yazarın Şeyh Cüneyd hakkındaki görüşleridir. Safeviler'e dair literatüre genel olarak bakıldığında Safeviyye tarikatının devletleşme süreci Şeyh Cüneyd ile başlatılır. Bu konuda araştırmacılar genel bir mutabakat içerisindedir. Çağdaş anlatılara dayalı yapılan 
incelemeler Cüneyd'e kadar tarikatın genel olarak Sünni bir çizgi takip ettiğini gösterir. Buna karşın Cüneyd döneminde meydana gelen faaliyetler ile birlikte tarikatın gayr-i Sünni ve askeri bir yapı kazanmaya başladığı belirtilir. Burada dikkat çekilmesi gereken husus araştırmacıların Cüneyd döneminde meydana gelen bu dönüşümü tamamen şeyhin karakterine dayandırmalarıdır. Fakat konuya farklı bir açıdan yaklaşan Yıldırım ileri sürdüğü tezinde Cüneyd'in şeyhlik makamına geldiğinde henüz 15 yaşından küçük ve öldüğünde yaklaşık yirmili yaşlarda olduğunu belirterek onun böyle radikal bir dönüşümün başlatılmasında tek başına etkin olamayacağını ileri sürer. Yazara göre dönüşümü yaratan asıl unsur daha önce de belirttiğimiz gibi zamanın ruhu olan Türkmenlerdi. Yıldırım'a göre burada değişimi sağlayan etmen aslında başka bir değişimdi. Erdebil dergahının ziyaretçi profiline bakıldığında Şeyh Cüneyd dönemine gelinceye kadar büyük ölçüde yerleşik kültürden kimselerin bulunduğu görülür. Yıldırım'a göre son dönemde ivme kazanan göçebe kültürünü temsil eden mürit sayısındaki artış, bu grupların tarikat içinde önemli bir nüfuz elde etmesini sağladı. Doğal olarak say1s1 yükselen göçebe kitlenin sosyo-kültürel yapısının tarikatın uygulamalarına ve inanç kalıplarına etki etmesi kaçınılmazdı. Bu durum Cüneyd döneminde tarikat içinde bir ayrışma meydana getirdi. Yeni akımın temsilcisi olan ya da desteğini alan şeyh, eski akımın destekçisi olan amcasının baskısı karşısında Erdebil'i terk etmek zorunda kaldı. Bu ayrışma aslında yerleşik ve göçebe kültürler arasında doğan gerginliğin bir tezahürüydü.

Erdebil'den ayrılış sonrası Anadolu'da başlayan seyahat güzergâhına baktığımızda şeyhin Türkmen nüfusunun yoğun olduğu noktaları ziyaret ettiğini görürüz. Bu süreç boyunca genç Cüneyd'in etrafındaki ana unsurlar Türkmenler'den oluşuyordu. Yıldırım'a göre Cüneyd'in fikirleri ve inançları esas olarak bu seyahat sırasında şekillendi. Bu süreçten sonra esnek karaktere sahip Türkmen dindarlığı ve savaşçı kültürü Safeviyye geleneğine sirayet ederek Kızılbaş telakkisinin, Alevi İslam'ının temelini oluşturdu. Erdebil'den ayrılan genç Cüneyd'in Anadolu'da yürüttüğü diplomasi, verdiği mücadele, Trabzon surlarına dayanması ve Gürcistan'a müritleri ile yaptığı gazalar Türkmenlerin onun ve tarikat üzerindeki açık etkisini göstermektedir. Cüneyd sonrası süreçte Haydar ve İsmail'in macerasını ele alan yazar, tıpkı ataları Cüneyd gibi henüz çocuk yaşta tarikatın başına geçen bu şeyhlerin ardında bulunan kollektif aklı vurgulamakta ve İsmail dönemindeki Lahican sufilerini örnek göstermektedir. Bundan sonraki süreçte İsmail'in hurucunu ve Safevi hareketinin devletleşmesini ele alan yazar hareketin Anadolu'daki yankılarını ve buna karşı alınan tedbirlerden bahsedip Kızılbaş hareketinin sönüşü ile eseri tamamlar. 
Son kısım, Kızılbaş hareketinin akıbeti bakımından ilginçtir. Aşiret konfederasyonu şeklinde teşekkül eden Safeviler, tıpkı Osmanlılar gibi devlet yapılarının doğası gereği bürokratikleşmeye başladılar. İranlı kalem sınıfının devlet kadrolarında etkisinin artması ile etkisi azalmaya başlayan Kızılbaş hareketi zamanla tarih sahnesinden çekildi. Bu minvalde hareketin etkisinin azalmasına dair ilk işaretlerin İsmail'in tahta çıktığı süreç gibi erken bir dönemde görülmesi oldukça dikkat çekicidir. Öyle ki burada oluşturulmuş aşiret temelli Alevi İslam, Şah İsmail'in faaliyetleri ile zamanla yerini yerleşik kültür temelli On iki İmam Şia'sına bıraktı. Böylece bin bir emekle yeni bir devlet kuran Türkmenler için tarih bir kez daha tekerrür etmiş oldu. Bu bölüm için belirtilmesi gereken bir başka husus ise, modern araştırmacıların Şah İsmail'in dini düşüncelerine dair öne sürdükleri "kendini tanrı olarak görme" tezine karşın Yıldırım'ın öne sürdüğü, İsmail'in vahdet-i vücud anlayışına dair yorumunun konuya dair getirilen önemli bir bakış açısı olduğudur. Buna göre başta Minorsky olmak üzere şiirleri üzerinden Şah İsmail'in inanç dünyasını incelemeye çalışan araştırmacılar, İsmail'de kendisinin tanrısal bir yapıya sahip olduğu fikrinin bulunduğunu öne sürerler. Buna karşın yukarıda da belirtildiği gibi vahdet-i vücud anlayışının göz ardı edilmemesi gerektiğini bildiren Yıldırım, bu konuya açıklık getirerek şiirlerde geçen ifadelerin ilk anlamlarının alınmasının yapılan çalışmalar için problem yaratacağını belirtir.

Son olarak kitaba dair görüşlere yer verecek olursak öncelikle çevirmenin başarısını takdir etmek gerekir. Konuya dair İngilizce ve Farsça'dan çevrilen pek çok araştırma eserlerinin aksine Yıldırım'ın çalışması ele aldığı her bölümü açık ve akıcı bir şekilde okuyucuya sunmaktadır. Bu durum yazar ve çevirmen arasındaki yakın çalışmadan kaynaklansa gerekir. Bunun dışında kitaba dair bir diğer husus, konu hakkında muğlak kaldığını düşündüğümüz bazı kısımlardır. Öncelikle Cüneyd'in zihni altyapısının oluşumunu sağlayan Türkmen nüfusu, tarikat içerisinde neden Şeyh İbrahim'den itibaren ciddi miktarda artmaya başlamıştır? Bu durum Cüneyd öncesi Sünni ve yerleşik kültürü temsil ettiğini düşündüğümüz bir yapı için çok olası mıdır? Ayrıca Cüneyd'in Erdebil'den ayr1lışını sağlayan unsurlar da bizce biraz daha irdelenmesi gereken hususlardır. Eğer Anadolu seyahati Cüneyd için yeni bir düşünsel zemin oluşturan süreçse Cüneyd'in Erdebil'den ayrılmasına neden olan düşünsel zemin neyin sonucuydu? Zira Cüneyd'in dergahtan ayrılmasından önce bu yeni öğretileri tarikat içerisinde öğrenmesi zordur. Buna karşın amcası tarafindan uğradığı suçlamalar ve Cihan Şah'ın yazmış olduğu mektubun içeriği de tarihsel bir realitedir. Bu hususta sadece amca Şeyh Cafer'in hırsları sonucunda Cüneyd'in yalnızlaştırıldığı ve aşiret kültürü içinde yeni bir dini yoruma tarikat dışına itilerek sahip olduğunu düşünsek 
bile, Sünni karaktere sahip olduğu tahmin edilen tarikata Cüneyd öncesi süreçten itibaren meydana gelen Türkmen rağbeti bu yapı içerisinde başka dini damarların olduğu düşüncesini akla getirir.

Yazara dair belirtilmesi gereken ilk husus ise dönemin kaynaklarına dair giriş bölümünde yapmış olduğu literatür değerlendirmesi sonrası kaynaklar hakkında bilgi verme işlemini sadece dipnotlarda bırakmamasıdır. Yıldırım'ın her bölümde tartışmalı konular hakkında titizlikle çağdaş yazarların görüşlerini karşılaştırmalı olarak vermesi işlenen konu yanında Osmanlı, İran ve Akkoyunlu tarih yazımı hakkında okuyucunun tatmin edici bir perspektif kazanmasını sağlamıştır. Fakat bunun yanında yazarın başta Fazlullah b. Ruzbihan olmak üzere Safevi aleyhtarı söylemlerde bulunan yazarlara dair bazı vurgularının biraz hissi bir izlenim verdiğini belirtmek gerekir. Sonuç olarak Yıldırım'ın bu eseri gerek alana dair çok farklı boyutlardan konuyu ele alabilme özelliği, gerek Türkçe ve Farsça kaynaklar dışında Almanca, Fransızca ve İtalyan kaynaklarını kullanmas1, akıcı anlatımı, alana dair diğer uzmanlardan yaptığı karşılaştırmalı alıntılardan dolayı konuya ilgisi olanlar için bir başucu kitabı olma niteliği taşıdığının vurgulanması gerekir. 